\title{
Residual stresses, fatigue and deformation in cast iron
}

\author{
Mattias Lundberg
}

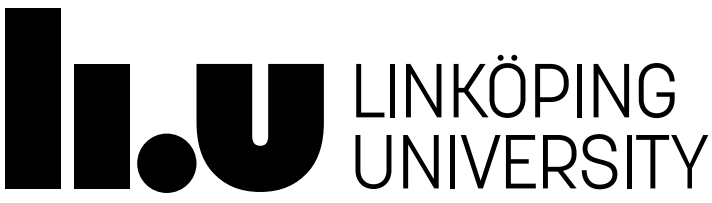

Division of Engineering Materials

Department of Management and Engineering (IEI) Linköping University, SE-581 83 Linköping, Sweden 
Front page image: Orientation imaging map utilizing cubic coloring of grey iron.

During the course of research underlying this thesis, Mattias Lundberg was enrolled in Agora Materiae, a multidiciplinary doctoral program at Linköping University, Sweden.

(c) Mattias Lundberg

ISBN 978-91-7685-358-0

ISSN 0345-7524

Printed by LiU-Tryck 2018 
The complex geometry of cylinder heads in heavy-duty diesel engines makes grey iron or compact graphite iron a preferred material choice due to its price, castability, thermal conductivity and damping capacity. Today's strict emission laws have increased the demands on engine performance and engine efficiency. This means that material properties such as fatigue resistance need to be improved. Shot peening is often used to improve the fatigue resistance of components and the benefits of shot peening are associated with the induced compressive surface stresses and surface hardening. How different shot peening parameters can affect fatigue strength of grey and compact graphite iron has been investigated within the project underlying this thesis. To do this, X-ray diffraction (XRD) was utilized for residual stress measurements, scanning electron microscopy (SEM) for microstructural characterizations and mechanical fatigue testing for mechanical quantifications. The ultimate aim of this work has been to increase the fatigue resistance of cast iron by residual stress optimization.

XRD measurements and SEM examinations revealed that the shot peening parameters shot size and peening intensity significantly influence residual stresses and surface deformation. Residual stress profiles, similar to the one general considered to improve the fatigue strength in steels, were obtained for both grey and compact graphite iron. Uniaxial push-pull fatigue testing on grey iron with these shot peening parameters reduced the fatigue strength with $15-20 \%$. The negative effect is likely related to surface damage associated with over peening and relatively high subsurface tensile residual stresses. With very gentle shot peening parameters, the uniaxial fatigue strength were unaltered from the base material but when subjected to bending fatigue an increase in fatigue strength were observed. An alternative way to increase the fatigue strength was to conduct a 30 min annealing heat treatment at $285{ }^{\circ} \mathrm{C}$ which increased the fatigue strength by almost $10 \%$ in uniaxial loading. The improvement could be an effect of favourable precipitates forming during the annealing, which could hinder dislocation movement during fatigue. 
Measuring residual stresses using XRD and the $\sin ^{2} \psi$-method demands accurate X-ray elastic constants (XEC) for meticulous stress analysis. The XEC referred to as $1 / 2 s_{2}$ should therefore always be calibrated for the specific material used. The experiments conducted revealed that the XEC value is independent of the testing method used in this work. A small correction from the theoretical value should be applied when the material contains small amounts of residual stresses. The amount of residual stresses has a great impact on the XEC and thus on the stress analysis. Concluding that proper analysis of residual stresses in cast iron is not straight forward. 


\section{Populärvetenskaplig sammanfattning}

Röntgen för en grönare miljö.

Hur kan röntgen bidra till en grönare miljö? Först måste det sägas att det inte är samma typ av röntgen som används på sjukhusen. Principen för att generera röntgenstrålningen är dock densamma, skillnaden ligger i utnyttjandet av dessa. Under vissa specifika förhållanden fås ett fenomen kallat röntgen diffraktion som kan ge forskaren värdefull insikt i materialets tillstånd. Röntgenstrålarnas penetrationsdjup är i storleksordningen av ett par mikrometer, vilket betyder att informationen som erhålls från det undersökta materialet är mycket ytnära. Inom projektet där detta avhandlingsarbete har genomförts har röntgen använts för att mäta restspänningarna i gjutjärn i just ytskiktet. Vad är då restspänningar och varför kan man behöva mäta dessa i gjutjärn för att få en grönare miljö? För att förstå vad restspänningar är tar vi ett exempel: när man böjer en ståltråd tillräckligt mycket kan den inte återgå till sitt initiala tillstånd. Då har man ett deformerat material med plastisk deformation. En effekt av denna förändring är också att restspänningarna har förändrats och den inneboende kraften som vill få tillbaka ståltråden till dess grundtillstånd har förändrats. Den här förändringen av materialet på atomnivå kan mätas med röntgendiffraktion och ge forskaren insikt i materialets tillstånd, t.ex. om hur mycket restspänningar som finns i ytskiktet. $\mathrm{Nu}$ när restspänningarna är introducerade behövs också förståelsen om varför de är intressanta. Vid upprepad belastning börjar ofta sprickor i materialet att växa från dess yta. Beroende på vilken typ av belastning, så kan restspänningar påskynda eller försena materialets sprickbildning. När sprickorna sedan har börjat växa är det inte så långt kvar till dess att materialet går sönder. Det har då blivit utmattat. Således kan man med rätt mängd restspänningar i ytskiktet förbättra materialets utmattningsegenskaper. Materialet klarar då högre belastning innan brott sker alternativt fler cykler. Gjutjärnets egenskaper har uppskattats av människan i ungefär 2500 år och gjutjärn besitter flera bra unika egenskaper som lämpar sig väl inom den tunga fordonsindustrin. Med gjutjärn kan man gjuta komplexa geometrier till nästan korrekta dimensioner, vilket gör 
att efterbearbetnings-kostnaderna inte behöver bli lika stora som om stål hade nyttjats. Det har även passande termiska egenskaper för de komponenter som kyls med vatten och olja i motorn. Dessutom har gjutjärn bra dämpande egenskaper vilket gör att vibrationerna från motorns taktfasta förbränning minskas radikalt gentemot andra metaller. Det är kostnadseffektivt att använda sig av gjutjärn för den tunga fordonsindustrin till komponenter som exempelvis cylinderhuvudena. Nackdelen är materialets mekaniska egenskaper som är relativt låga gentemot stål. Med hårdare utsläppskrav på dieselmotorer måste dagens aktörer på marknaden förbättra hela förbränningsprocessen för motorerna. Varje liten procent är av stor vikt för att uppnå de nya utsläppskraven som ställs. Ett sätt skulle vara att öka arbetstrycket i motorerna, vilket ställer högre krav på materialet i cylinderhuvudet. För att möta detta behöver man förstå och undersöka hur mycket man kan förbättra utmattningsegenskaperna hos gjutjärnen som idag används i motorerna genom att förändra ytskiktet, genom t.ex. optimering av restspänningarna. Med den forskning som gjorts i denna avhandling ges en förståelse av vad vi kan göra med materialets ytskikt för att förbättra dess utmattningsegenskaper. Slutligen kan motorerna bli effektivare och släppa ut mindre mängder skadliga avgaser vilket resulterar i en grönare miljö.

Vad är då restspänningar och varför kan man behöva mäta dessa i gjutjärn för att få en grönare miljö? För att förstå vad restspänningar är tar vi ett exempel: när man böjer en ståltråd tillräckligt mycket kan den inte återgå till sitt initiala tillstånd. Då har man ett deformerat material med plastisk deformation. En effekt av denna förändring är också att restspänningarna har förändrats och den inneboende kraften som vill få tillbaka ståltråden till dess grundtillstånd har förändrats. Den här förändringen av materialet på atomnivå kan mätas med röntgendiffraktion och ge forskaren insikt i materialets tillstånd, t.ex. om hur mycket restspänningar som finns i ytskiktet.

$\mathrm{Nu}$ när restspänningarna är introducerade behövs också förståelsen om varför de är intressanta. Vid upprepad belastning börjar ofta sprickor i materialet att växa från dess yta. Beroende på vilken typ av belastning, så kan restspänningar påskynda eller försena materialets sprickbildning. När sprickorna sedan har börjat växa är det inte så långt kvar till dess att materialet går sönder. Det har då blivit utmattat. Således kan man med rätt mängd restspänningar i ytskiktet förbättra materialets utmattningsegenskaper. Materialet klarar då högre belastning innan brott sker alternativt fler cykler.

Gjutjärnets egenskaper har uppskattats av människan i ungefär 2500 år och gjutjärn besitter flera bra unika egenskaper som lämpar sig väl inom den tunga fordonsindustrin. Med gjutjärn kan man gjuta komplexa geometrier till nästan korrekta dimensioner, vilket gör att efterbearbetningskostnaderna inte behöver bli lika stora som om stål hade nyttjats. Det har även passande termiska egenskaper för de komponenter som kyls med vatten och olja i motorn. Dessutom har gjutjärn bra dämpande egenskaper vilket gör att vibrationerna från motorns taktfasta förbränning minskas radikalt gentemot andra metaller. Det är kostnadseffektivt att använda sig av gjutjärn för den tunga fordonsindustrin till komponenter som exempelvis cylinderhuvudena. Nackdelen är materialets mekaniska egenskaper som är relativt låga gentemot stål. 
Med hårdare utsläppskrav på dieselmotorer måste dagens aktörer på marknaden förbättra hela förbränningsprocessen för motorerna. Varje liten procent är av stor vikt för att uppnå de nya utsläppskraven som ställs. Ett sätt skulle vara att öka arbetstrycket i motorerna, vilket ställer högre krav på materialet i cylinderhuvudet. För att möta detta behöver man förstå och undersöka hur mycket man kan förbättra utmattningsegenskaperna hos gjutjärnen som idag används i motorerna genom att förändra ytskiktet, genom t.ex. optimeraing av restspänningarna. Med den forskning som gjorts i denna avhandling ges en förståelse av vad vi kan göra med materialets ytskikt för att förbättra dess utmattningsegenskaper. Slutligen kan motorerna bli effektivare och släppa ut mindre mängder skadliga avgaser vilket resulterar i en grönare miljö. 

This research has been carried out at the Division of Engineering Materials, Department of Management and Engineering, Linköping University, Sweden. The project was funded by Sweden's innovation agency, Vinnova, Scanica CV AB, Volvo Powertrain, and through the faculty grant SFO-MAT-LiU\#2009-00971 which are gratefully acknowledged. During the course of research underlying this thesis, I was enrolled in Agora Materiae, a multidiciplinary doctoral program at Linköping University, Sweden. Thank you prof. Per-Olof Holtz for running the graduate school Agora Materiae.

During the course of this work I have received help from many, without whom I would probably not have finished my Ph.D. Therefore, I would like to express my sincere gratitude to: My supervisors prof. Johan J. Moverare and prof. Ru Lin Peng, for giving me the opportunity to study residual stresses, fatigue and deformation behaviour of cast iron. To my industrial cosupervisors Ph.D. Taina Vuoristo, and Ph.D. Daniel Bäckström from Scanica CV AB, and Ph.D. Maqsood Ahmad from Volvo Powertrain for industrial application problems and material testing. And to my cosupervisors from academia prof. emeritus Sten Johansson and Ph.D. Mattias Calmunger for discussions during the time as a Ph.D. student.

To my office coworker I send an extra thank you and acknowledgement, without you Jonas Saarimäki I would not have come this far.
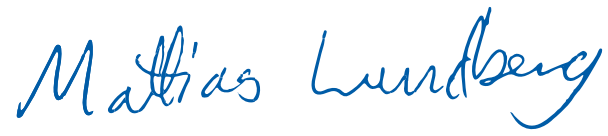

Mattias Lundberg

Linköping, Maj 2018 

1 Introduction $\quad 1$

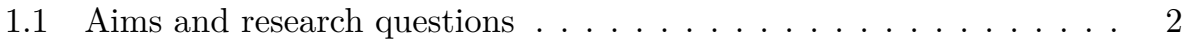

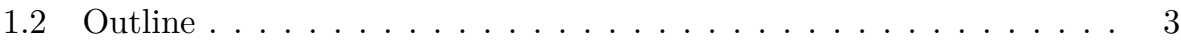

2 X-ray diffraction 5

2.1 What are X-rays? . . . . . . . . . . . . . . . . 5

2.2 Residual stresses . . . . . . . . . . . . . . . . . 8

$2.3 \sin ^{2} \psi$-method . . . . . . . . . . . . . . . . . . . . . . . . . . . . . 10

2.4 Diffraction peak analysis . . . . . . . . . . . 11

3 Cast Iron $\quad \mathbf{1 3}$

3.1 Graphite and matrix . . . . . . . . . . . . . . . . 13

3.2 Cast iron thesis . . . . . . . . . . . . . . . 15

4 Shot peening $\quad 17$

4.1 Shot peening of cast iron . . . . . . . . . . . . . 18

5 Fatigue 19

5.1 Fatigue of cast iron . . . . . . . . . . . . . . . . . 19

5.2 Residual stresses and fatigue . . . . . . . . . . . . . . . . 21

5.3 Fatigue testing conducted . . . . . . . . . . . . 22

6 Microscopy $\quad \mathbf{2 3}$

6.1 Electron channelling contrast imaging . . . . . . . . . . . . 23

6.2 Electron backscatter diffraction . . . . . . . . . . . . . . 23

6.3 Differences between ECCI and EBSD . . . . . . . . . . . . 25

7 Review of appended publications $\quad \mathbf{2 7}$

7.1 Scientific contribution . . . . . . . . . . . . . . 32 
8 Outlook 33

9 List of publications $\quad 35$

$\begin{array}{ll}\text { Bibliography } & 39\end{array}$

$\begin{array}{ll}\text { Paper I } & 45\end{array}$

Paper II $\quad 55$

$\begin{array}{ll}\text { Paper III } & 65\end{array}$

$\begin{array}{ll}\text { Paper IV } & 77\end{array}$

$\begin{array}{lr}\text { Paper V } & 85\end{array}$

$\begin{array}{ll}\text { Paper VI } & 93\end{array}$

$\begin{array}{ll}\text { Paper VII } & 103\end{array}$

$\begin{array}{lc}\text { Paper VIII } & 113\end{array}$ 


\section{CHAPTER 1}

\section{Introduction}

This thesis has been a part of the project FFI-Increased fatigue strength of cast iron components through optimization of residual stresses which started during the winter 2010/2011. The project was financed by Vinnova and was performed as a collaboration between Linköping University, Scania CV AB and Volvo Powertrain. Cast iron are "state of the art" materials for cylinder heads in heavy-duty diesel engines and with the increasing demand on fuel efficiency and lower emissions something needs to be done to meet the criteria. A way to meet these criteria could be achieved by increasing the combustion temperature and working pressure. This raises the demands on the material used from a fatigue point of view. An increase in fatigue performance can often be achieved by introducing surface residual stresses. Residual stresses can be detrimental or beneficial for a component depending on load case and sign of the residual stresses. Optimizing the residual stress field at critical positions in the component should make it possible to increase the diesel engine working pressure. Increased fatigue strength of the material could also enable a weight reduction of components as thinner walls could be used. Better understanding of the correlation between manufacturing methods, residuals stresses and fatigue strength will provide the industry an advantage in designing new and durable components.

Cylinder heads for heavy truck applications are manufactured of grey iron or compact graphite iron. Grey iron exhibits a number of positive physical properties such as castability, high thermal conductivity and good damping capacity. Complex geometries also limits the material selection and manufacturing methods. Utilizing grey iron has one big downside, it has a relatively low fatigue strength. Compact graphite iron has slightly better fatigue properties but is more difficult to cast and has not as high thermal conductivity as grey iron. Several researchers have increased the fatigue strength on different components by shot peening, a common process used to increase fatigue resistance. Shot peening induces ben- 
eficial compressive surface residual stresses. The effects of shot peening and its induced compressive residual stress field in cast iron, especially grey iron, has not yet been thoroughly studied. Tailoring residual stresses at critical locations using shot peening offers a cost effective alternative to increase the fatigue performance of components and as a result meeting the ever increasing requirements of engine performance.

Measuring residual stresses with X-ray diffraction (XRD) requires good equipment and the analysis is not trivial for these anisotropic multiphase materials studied in this work. Obtaining correct residual stress values using XRD and the $\sin ^{2} \psi$-method also requires accurate X-ray elastic constants (XEC:s) and should be experimentally determined.

\subsection{Aims and research questions}

The Swedish Governmental Agency of Innovation Systems, Vinnova, has the global goal "To strengthening Sweden's innovativeness, aiding sustainable growth and benefiting society". Within Vinnova was a program called "Strategic Vehicle Research and Innovation". This thesis has been carried out under the umbrella of the sub program "Provide the vehicle industry with innovative materials and access to new state of the art material use".

Increasing the fatigue strength of cast iron components by tailoring residual stresses was the main goal of my part of the program. To achieve this, the following aspects have been focused on during my time as a Ph.D. student:

- Development of fast and reliable residual stress measurement methods.

- Predicting residual stress fields as a result of surface treatments such as machining and shot peening.

- Understanding the importance of residual stresses related to the fatigue life of cast iron.

Focus has also been put on utilizing the methods on other metallic materials such as stainless steel and additively manufactured (AM) selective laser melted (SLM) superalloy. The following research questions have been addressed:

1. Can X-ray diffraction be used to measure residual stresses in cast iron both fast and accurate?

This needed examining due to the vast interest from the involved industrial partners.

2. Can shot peening be used to induce beneficial residual stresses in cast iron?

Shot peening is commonly used to increase fatigue strength of metallic components by inducing beneficial residual stresses. The effect of shot peening on grey and compact graphite iron is still unknown. Therefore, peening parameters are of great importance to induce beneficial residual stresses. 
3. Is it possible to increase the fatigue properties of cast iron by utilizing post treatments such as shot peening?

It is not evident that fatigue strength of grey and compact graphite iron can be significantly increased with the help of shot peening, as a consequence of their complex microstructure.

4. Which are the dominating deformation mechanisms present in cast iron?

It is important to understand the deformation behaviour of cast iron in order to improve the fatigue strength.

5. Are the techniques used only applicable when investigating cast iron or can they be used on other metallic materials?

This was more of an academic interest to investigate the versatility of the techniques used. I was fortunate enough to be presented with the possibility to run similar tests on stainless steel and AM SLM superalloy. The latter mentioned could be considered as a new material group since the SLM process yields a unique microstructure.

\subsection{Outline}

This thesis comprises of two parts. Part I aims to give the non-seasoned expert an introduction to the world of X-rays, cast iron, and fatigue, providing the reader with a glimpse of their complexity. At the end of the first part we have the summary of the appended publications and future work. Part II consists of VIII appended publications.

This dissertation has been built upon my licentiate thesis Residual stresses and fatigue of shot peened cast iron from October 2013. 


\section{CHAPTER 2}

\section{X-ray diffraction}

X-ray diffraction is an important and powerful tool for material investigations. It can be used to analyse and determine material characteristics such as internal structures, chemical phases, crystal quality, crystal size, layer thickness, surface and interface roughness, crystal orientation, texture, lattice parameter but most importantly stress measurements. Even though XRD has such a wide field of use in materials characterisation, complementing methods might also be needed to better understand and determine material properties. Using XRD for material characterisation can be easy and straight forward. However, analysing and understanding the obtained diffraction data is not arbitrary unless you have an understanding of the underlying fundamental physics.

\subsection{What are X-rays?}

Wilhelm Conrad Röntgen received the first Nobel price in physics, 1901. He had observed a new kind of rays, which travelled through paper, wood and aluminium, which he called $X$-radiation. The discovery was made November 8, 1895 . In 1912, Max von Laue showed that atoms are periodically ordered in crystals and that X-rays are electromagnetic waves. He discovered the diffraction of X-rays by crystals and received the Nobel price 1914 in physics. The Bragg's (father and son) built the first X-ray diffractometer and formulated the first equation used to calculate the diffraction peaks relating dependency of wavelength and crystal structure. For this work, they received the Nobel prize in 1915 "for their services in the analysis of crystal structures by means of X-rays".

As discovered by Max von Laue X-rays are electromagnetic radiation and are of the same nature as light but of a much shorter wavelength. X-ray wavelengths are in the range of $\sim 0.5-50 \AA$ Angström, $[\AA]$, whereas the wavelength of visible light 
is in the region of $6000 \AA$. Different electromagnetic wavelengths are illustrated in Figure 2.1.

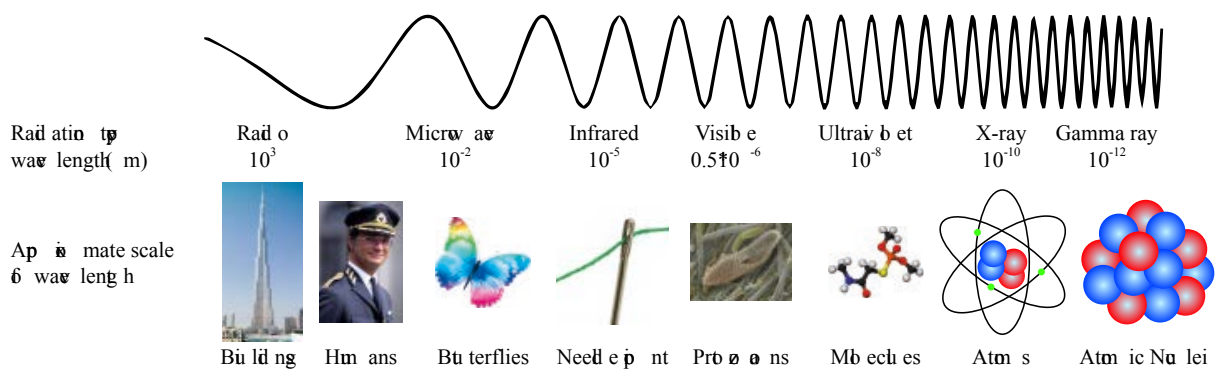

Figure 2.1. Nature of electromagnetic waves.

Any accelerated or decelerated electrical charge, radiates energy. Radio waves are generated by charges oscillating in broadcasting antennas. Visible light emits from atoms by oscillation of electrons of the substance. X-rays are produced when any electrically charged particle with sufficient kinetic energy is rapidly decelerated or accelerated. Commonly highly energetic electrons are used to generate X-rays. When the charged particles are decelerated while colliding with a target material, electromagnetic waves are generated. Less than one percent of the kinetic energy in the electrons is transformed into X-rays. The electron penetrates the target material and interacts with its electron cloud and continuously decelerates. This continuous deceleration gives continuous radiation, which is called Bremsstrahlung or white radiation. When the kinetic energy of the electron exceeds the ionization threshold of the target material, the incoming electron will eject a core electron. Now the atom is lacking one electron in the K-shell and is thereby unbalanced. An electron from a higher shell will then "jump down" to fill the hole in the K-shell. While doing so, it looses some of its energy by radiating X-ray photons. Since the energy levels of the atoms are fixed, the radiated X-rays will have a specific wavelength (energy) which are characteristic for all elements. This is the characteristic radiation which is of great importance to material scientists.

As discovered and shown by the Bragg's, X-rays will interact with the atomic planes in the crystal and at certain conditions constructive interference will occur. When the angle of the incident beam, $\theta$, and diffracted beam are the same, and the path difference between the planes are an even number of wavelength, constructive interference can occur. Now we use the characteristic wavelength, $\lambda$, to fulfil this requirement and the path difference we normally connect with the distance between the crystallographic planes $d_{h k l}$. This relationship is illustrated in Figure 2.2 and known as Bragg's law accordingly:

$$
n \lambda=2 d_{h k l} \sin \theta
$$

where $n$ is an integer. 


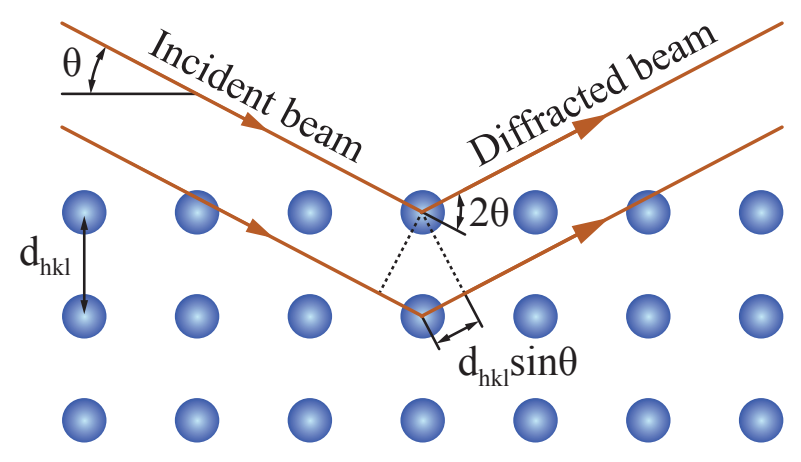

Figure 2.2. Constructive interference when $n \lambda=2 d_{h k l} \sin \theta$.

When changing the incident, and diffraction angel continuously we do what is known as a $\theta-2 \theta$ scan. In the field of materials research, the $\theta-2 \theta$ scan using $\mathrm{X}$-ray diffraction is important since it is a fast method used to obtain material characteristics such as unit cell dimensions, unit cell content, presence of strains and crystallite size from the irradiated volume. However, there are multiple factors affecting the diffraction data obtained from the $\theta-2 \theta$ scan. Depending on what information is looked for, some of these factors can be either disregarded or must be carefully considered. Nicely enough, these factors have been well studied, and how they contribute to the peak intensity distribution of the $\theta-2 \theta$ scan can be discribed accordingly:

$$
I=S C F \cdot m_{h} \cdot T_{h} \cdot L_{p} \cdot\left|F_{h}\right|^{2} \cdot A_{\theta-2 \theta},
$$

where $S C F$ is a scaling factor lumping up all instrumental settings like scan velocity, $\dot{\theta}$, slit width etc., allowing the comparison of integral intensities from one diffraction pattern on a relative scale. $m_{h}$ is the multiplicity factor taking the probability for a grain to be positioned in such way that a certain plane fulfills Bragg's law compared to another plane. $T_{h}$ is the texture factor taking into account if there is a preferred orientation in the material. $L_{p}$ is the Lorentz-polarisation factor. $\left|F_{h}\right|^{2}$ is the structure factor, accounting for effects depending on crystallographic system and $A_{\theta-2 \theta}$ is the absorption factor.

When conducting residual stress measurements, a shift in diffracted peak position (same peak, same specimen) indicates a presence of residual stresses (strains). This peak shift can be seen by collecting diffraction data over the same $2 \theta$ range where the peak of interest is positioned, while tilting the specimen in a clever way. Then all the previously mentioned factors can be neglected when doing residual stress measurements. This is the basis of the $\sin ^{2} \psi$-method for measuring residual stresses. 


\subsection{Residual stresses}

The term residual stress used by engineers is related to local variations in strains inside materials on a macroscopic or microscopic level without any external load acting on the material. They arise from an elastic response to an inhomogeneous distribution of non-elastic strains. The most common sources of non-elastic strains, and thus residual stresses, are plastic deformation, phase incompatibility and thermal expansion strains. Strains can be converted into stresses via XEC. This constant varies with material and diffraction plane used [1, 2]. Stress as unit is fundamentally easier to grasp for most people and is defined as the force acting on a specific area.

Residual stresses can be divided into macro- and microstresses [1-3]. Macrostresses are self equilibrated through the cross section of the work piece and reaching over a longer length scale than the material grain size. An example of macrostresses are residual stresses after machining. The microstresses are found between and inside the grains.

Casting residual stresses are present in the as-cast condition in all castings due to differences in cooling rates in different parts of the component during solidification, strength of the mould and cleaning of the cast work piece. The main contributors to residual stresses that needs to be kept in mind when casting are cooling rates and blast cleaning, or rather the energy of the blast cleaning process. When casting complex geometries, wall thickness often differs much and does not only affect the thermal residual stresses but also the microstructure of the component. Sand moulds are commonly used for casting grey iron and to remove the sand residues, blast cleaning is often applied. Considerable amounts of surface residual stresses can be introduced depending on the energy output of the blasting medium.

The forces associated with stresses in a material are not measured, instead the strain(s) is measured and then calculated into stresses. Depending on the stress measurement technique used, the conversion from strains to stresses may differ. It is actually more correct to say that we are measuring residual strains and not residual stresses. Since this thesis focuses on utilizing XRD to measure residual stresses in grey and compact graphite iron, we shall now continue with an introduction to basic residual stress measurements with X-rays.

Firstly, a coordinate system is needed and the usage of Cartesian coordinate system as origin to define the specimen (S) and the laboratory (L) system, shown in Figure 2.3. Once the constitutive equations that describe the two coordinate systems are expressed we can apply these to the method used in this project to measure the residual stresses with X-rays. The stresses (strains) are defined in the specimen coordinate system and $\mathrm{L}_{\phi \psi}$ direction is the bisectrise between the incoming and the diffracted X-ray beam, defined by the two angles $\psi$ and $\phi$.

From this relation we can derive the strain equation from the sample coordinates to our laboratory system and vice versa. The calculated stresses and strains will be expressed in the sample coordinate system. By tensor transformation we can then write the normal strains in the sample expressed from strains obtained in the $\mathrm{L}_{\phi \psi}$ direction as $[1,2,4]$ : 


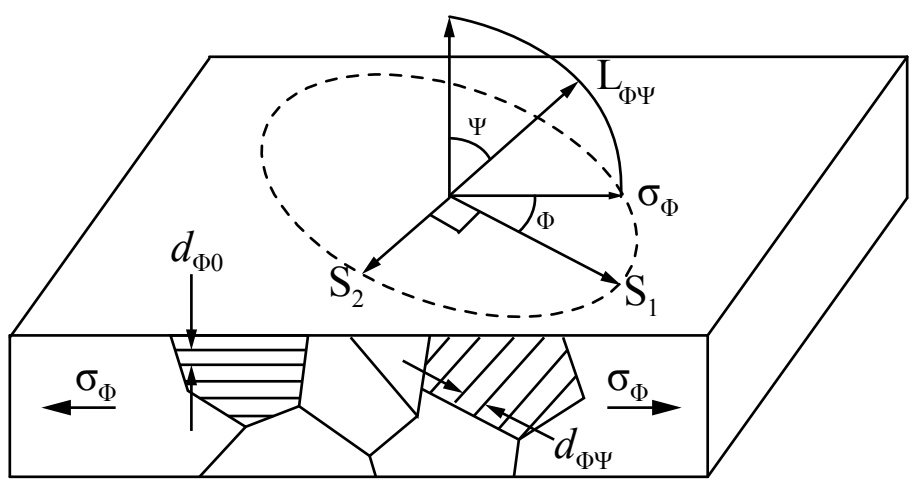

Figure 2.3. Coordinate systems used for XRD stress measurements.

$$
\begin{aligned}
\varepsilon_{\phi \psi}=\frac{d_{\phi \psi}-d_{0}}{d_{0}}=\varepsilon_{11} \cos ^{2} \phi \sin ^{2} \psi+\varepsilon_{22} \sin ^{2} \phi \sin ^{2} \psi+\varepsilon_{33} \cos ^{2} \psi \\
+\varepsilon_{12} \sin 2 \phi \sin ^{2} \psi+\varepsilon_{13} \cos \phi \sin 2 \psi+\varepsilon_{23} \sin \phi \sin 2 \psi
\end{aligned}
$$

For an isotropic material, the relationship between strains and stresses can be utilized by Hook's law accordingly:

$$
\varepsilon_{i j}=\frac{1+\nu}{E} \sigma_{i j}-\frac{\nu}{E} \delta_{i j}\left(\sigma_{11}+\sigma_{22}+\sigma_{33}\right),
$$

where $\delta_{i j}$ is the Kronecker delta function, $\delta_{i j}=1$ if $\mathrm{i}=\mathrm{j}$ otherwise zero.

The combination of Eq: 2.3 and Eq: 2.4 results in the general working equation for X-ray stress analysis:

$$
\begin{aligned}
\frac{d_{\phi \psi}-d_{0}}{d_{0}}=\frac{1+\nu}{E}\left(\sigma_{11} \cos ^{2} \phi\right. & +\sigma_{12} \sin ^{2} \phi \\
+\frac{1+\nu}{E} \sigma_{33}-\frac{\nu}{E} & \left(\sigma_{11}+\sigma_{22}+\sigma_{33}\right) \\
& \sin ^{2} \psi \\
& +\frac{1+\nu}{E}\left(\sigma_{13} \cos \phi+\sigma_{23} \sin \phi\right) \sin 2 \psi
\end{aligned}
$$

This holds for an isotropic material if $\varepsilon_{i j}$ is homogeneous within the penetration depth of the X-rays, giving us two major assumptions for using XRD to measure residual stresses.

With this stress measurement technique, the crystal lattice is used as an internal strain gauge and by comparing the stressed lattice spacing $\left(d_{\phi \psi}\right)$ with the unstressed lattice spacing $\left(d_{0}\right)$, the strain can be calculated accordingly:

$$
\varepsilon_{\phi \psi}=\frac{d_{\phi \psi}-d_{0}}{d_{0}} .
$$




\section{$2.3 \sin ^{2} \psi$-method}

The most common way to measure residual stresses with X-rays is the $\sin ^{2} \psi$-method and assuming biaxial stress state. Biaxial (plane) stress state is the assumption that we only have stresses in the plane and that no stresses normal to the surface exists. This is a fair assumption since the penetration depth of the X-rays are between 1 and $50 \mu \mathrm{m}$ depending on radiation source and target material [1]. This makes the evaluation of the residual stresses easier. Next assumption needed making it possible to measure stresses with this technique is that the lattice spacing normal to the surface is the same as the material parameter $d_{0}$ for the diffracted plane when $\psi=0^{\circ}$. With these assumptions made, Eq 2.5 and Eq 2.6 can be reduced to the following:

$$
\varepsilon_{\phi \psi}=\frac{d_{\phi \psi}-d_{0}}{d_{0}}=\frac{1+\nu}{E} \sigma_{\phi} \sin ^{2} \psi-\frac{\nu}{E}\left(\sigma_{11}+\sigma_{22}\right) .
$$

Since biaxial stress state is assumed, the surface stress component $\sigma_{\phi}$ is calculated accordingly:

$$
\sigma_{\phi}=\sigma_{11} \cos ^{2} \phi+\sigma_{12} \sin 2 \phi+\sigma_{22} \sin ^{2} \phi
$$

The $\sin ^{2} \psi$-method has the huge advantage of measuring the stresses in the sample without knowing the unstressed lattice spacing $d_{0}$. Or rather the assumptions made leads to this, but it is a very convenient assumption that only results in an error in stress reading $<1 \%$ [4].

When $\psi=0$ then Eq 2.7 reduces to its last component:

$$
\varepsilon_{\phi 0}=\frac{d_{\perp}-d_{0}}{d_{0}}=-\frac{\nu}{E}\left(\sigma_{11}+\sigma_{22}\right),
$$

where $d_{\perp}$ denotes the lattice spacing parallel to the specimen surface normal instead of $d_{0}$. By substituting Eq 2.9 into Eq 2.7 we can rewrite the equation accordingly:

$$
\frac{d_{\phi \psi}-d_{\perp}}{d_{0}}=\frac{1+\nu}{E} \sigma_{\phi} \sin ^{2} \psi
$$

Since $d_{\perp} \approx d_{0}$ due to the negligible error [4], allows the replacement of $d_{0}$ in Eq 2.10 with $d_{\perp}$ resulting in the final version of the working equation used for this method accordingly:

$$
\frac{d_{\phi \psi}-d_{\perp}}{d_{\perp}}=\frac{1+\nu}{E} \sigma_{\phi} \sin ^{2} \psi .
$$

With the help of Eq 2.11, the reader should be able to see the linear dependency of the measured lattice spacing, $d_{\phi \psi}$ and $\sin ^{2} \psi$. In practise, several measurements are made in different $\psi$-angles at specific $\phi$-angle. By plotting the obtained lattice spacing data against $\sin ^{2} \psi$, the slope of the fitted line contains the information of the measured surface stresses $\sigma_{\phi}$ as illustrated in Figure 2.4. By dividing the slope value $m$ with $(1+\nu) / E$, the component $\sigma_{\phi}$ can be solved using the $d_{\perp}$.

The terms $-\nu / E$ and $(1+\nu) / E$ in Eq 2.7 relates elastic data for the diffraction plane utilized to the residual stresses measured with X-rays [5]. They are both 


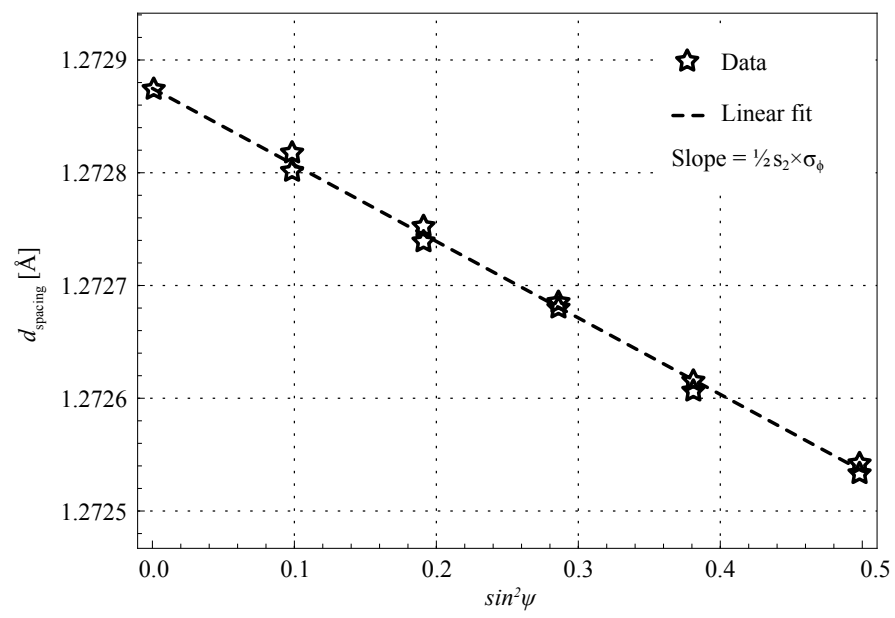

Figure 2.4. Data used to calculate residual stresses using $\sin ^{2} \psi$-method.

important in X-ray analysis and commonly called XEC $s_{1}$ and $1 / 2 s_{2}$ respectively. Since the Young's modulus depends on the crystallographic plane studied, a more correct notation would be:

$$
\begin{gathered}
\frac{-\nu}{E_{h k l}}=s_{1(h k l)}, \\
\frac{1+\nu}{E_{h k l}}=\frac{1}{2} s_{2(h k l)} .
\end{gathered}
$$

\subsection{Diffraction peak analysis}

Gathering data from a diffraction peak is fairly easy, problems arise when analysing the data to something useful. Diffraction data can, and should be treated differently depending on the type of measurement conducted. Consequently, the results contains different information. An example of diffraction peak data is illustrated in Figure 2.5. For stress analysis, it is very important to accurately determine the peak-position as mentioned previously. The idea with stress measurements utilizing the lattice planes as internal strain gauges and small changes in lattice spacing leads to a shift in peak position. Accurate peak position determination depends on both the quality of the diffracted data (goniometer and detector resolution and step size for data acquisition) and on peak separation technique.

The software used in this dissertation work, separates the diffraction data into three components background noise, $K_{\alpha_{I}}$ diffraction peak, and $K_{\alpha_{I I}}$ diffraction peak using a double pseudo-Voight peak fitting. Only the diffraction data from the $K_{\alpha_{I}}$ are used for the stress analysis, since it is the strongest diffraction peak.

Peak broadening analysis can be important to the material researcher that uses X-rays for material characterisation. The main broadening effects in a ma- 


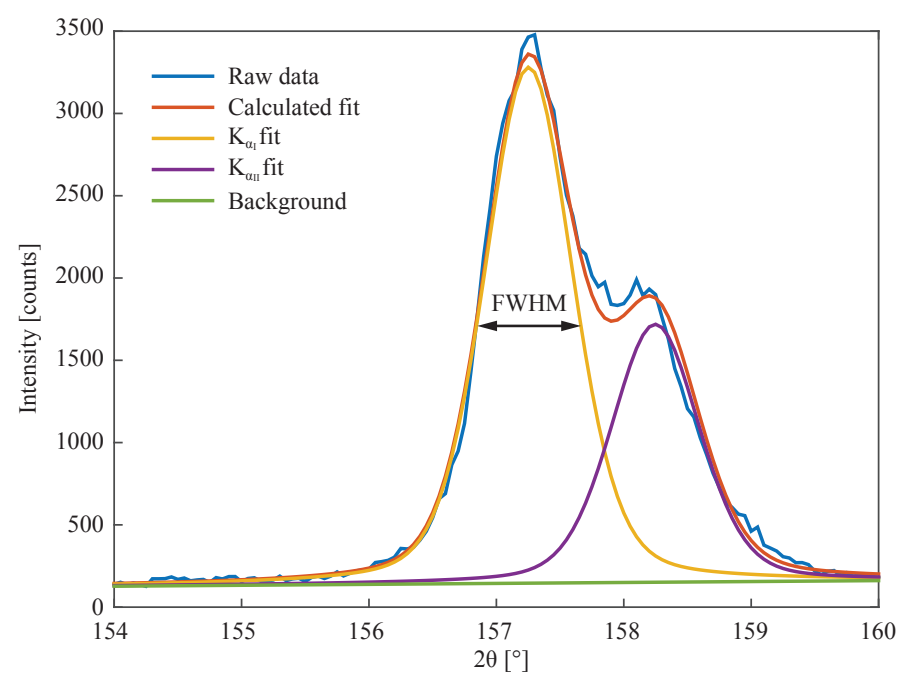

Figure 2.5. Diffraction peak separation.

terial comes from an inhomogeneous strain in the gauge volume and from beam divergence. Within this thesis, the peak broadening effects have been analysed as the stressed material is removed and the amount of inhomogeneous strains diminished. The peak width at half the height of the peak is calculated and referred to as the full width at half maximum (FWHM) indicated by the arrow in Figure 2.5. FWHM-values are qualitative data on the degree of plastic deformation in the irradiated volume, if the same instrumental set up is used for each measurement $[1,3]$. Material was electrolytically removed between measurements and residual stress and FWHM profiles were obtained. These profiles contain information regarding residual stress distribution and degree of plastic deformation. 


\section{CHAPTER 3}

\section{Cast Iron}

In the beginning of $19^{\text {th }}$ century cast iron was divided into two different groups based on fracture surface color, grey iron or white iron. As light optical microscopes evolved, scientists started to investigate the material and found that the shape of the graphite varied, but still giving the same grey fracture surface. More classifications were needed and the shape of the graphite have since then been used to classify cast iron. As metallurgy was breaking new grounds, different amounts of alloying elements and their effects on mechanical properties were investigated and a more narrow classification of cast iron were needed.

The term cast iron identifies a large group of ferrous alloys were the carbon content is greater than the solubility of carbon in the austenite phase. Cast iron consists of many different alloys where the most important alloying elements are carbon, silicon, magnesium and manganese which all strongly influence the microstructure. To make matters more complex, the following factors should be religiously considered while casting: chemical composition, cooling rate(s), liquid treatment, mould stiffness, mould geometry and heat treatment $[6,7]$.

\subsection{Graphite and matrix}

Many parameters affect the outcome of the casting, therefore, it becomes natural to classify cast iron depending on graphite shape. Both the ASTM and the ISO standard divides cast iron similarly and is briefly described here.

The seven primary shapes of graphite in cast iron can be found in reference [6] and in ASTM A247 and ISO 945-1. Once the shape is identified, the next step is to determine graphite dimension and distribution, following the standard.

In both ASTM and EN ISO standard, graphite size in cast iron should be mentioned from the foundry alongside with the mechanical properties (if required 
by the customer). For grey iron the graphite sizes are divided into eight different categories according to ISO 945-1 standard. The sizes are based on the longest flake size and expands from $100 \mathrm{~mm}$ or more down to the smallest category of flake size of less than $1.5 \mathrm{~mm}$ in dimension. Flake size refers to the perceived size in $\times 100$ magnification, thus the actual flake size is 100 times smaller. This is almost the same as for the ASTM standard but utilizing imperial system instead of the metric system.

Generally the smaller graphite sizes are associated with faster cooling in iron with high carbon equivalent values when investigating grey iron properties. The attributed changes in properties of grey iron consisting of large flake sizes are high thermal conductivity and good damping capacity on the cost of mechanical strength. Hypoeutectic iron subjected to rapid cooling (not quenching) generally provides very small flake sizes resulting in higher tensile strength. The last classification step for cast iron concerns graphite distribution and is depicted in Figure 3.1 for grey iron.

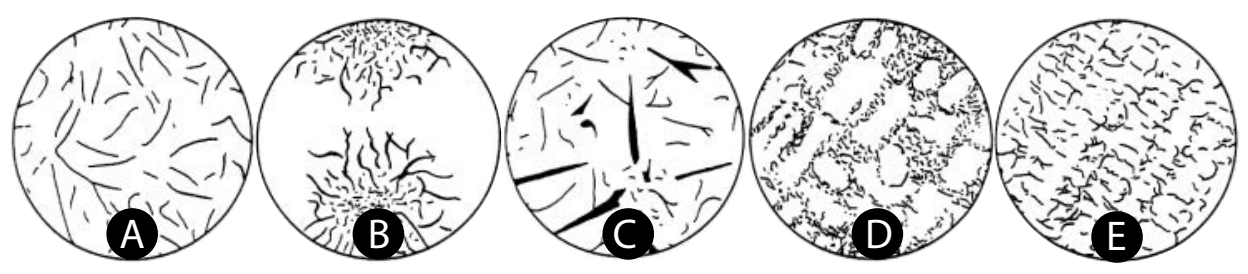

Figure 3.1. Graphite distribution in grey cast iron according to ASTM and ISO 945. Type A Random flake graphite in a uniform distribution. Type B Rosette flake graphite. Type C Kish graphite (hyper-eutectic compositions). Type D Undercooled flake graphite. Type E Interdendritic flake graphite (hypo-eutectic compositions).

Depending on the graphite morphology, different mechanical properties can be achieved with the same type of matrix. For example, a pearlitic grey iron with a nominal graphite length of $150 \mu \mathrm{m}$ has better damping qualities but lower ultimate tensile strength than a pearlitic graphite cast iron with a nominal flake length of $20 \mu \mathrm{m}$. Needless to say but the graphite morphology is crucial for the physical properties of grey iron.

It is important to classify the amount of fully spheroidal graphites as well as the degree of roundness and their size for compact graphite iron and spheroidal graphite iron.

One of the following matrices can be achieved for cast iron: ferrite, pearlite, austenite, martensite or bainite (often called austempered). Most common are pearlite or ferrite-pearlite matrix in grey and compact iron components. Ferrite is the soft low-carbon $\alpha$-Fe phase that has low tensile strength but good ductility. Ferrite is often found in conjunction with undercooling.

Pearlite is the eutectoid transformation from austenite to a lamellar structure of the softer ferrite and the harder intermetallic phase cementite. The hardness and tensile strength of pearlite are higher than that of ferrite but with lower ductility. With a shorter distance between the lamellas of ferrite and cementite, 
the hardness and tensile strength in the material increases. The lamellar spacing and thereby the mechanical properties can be controlled with more rapid cooling of the casting or by adding alloying elements.

A comparison of the mentioned microconstituents in hardness yields an increase from 75 to 200 to $550 \mathrm{HB}$ for the ferrite, pearlite and cementite respectively. Tensile strength and elongation of ferrite are roughly $280 \mathrm{MPa}$ and $60 \%$ respectively and pearlite has a tensile strength $>850 \mathrm{MPa}$ and $10 \%$ elongation.

\subsection{Cast iron thesis}

In this thesis, the main cast iron investigated were grey cast iron equivalent to ENGJL-300 and compact graphite iron equivalent to EN-GJV-400 supplied by Scania $\mathrm{CV} \mathrm{AB}$ and Volvo Powertrain. The microstructure in cast iron can vary significantly leading to large variations in mechanical properties. Which are detrimental for researchers when studying material properties. To minimize these effects on the research results, the material used for each and every round of testing were taken from the same batch. The typical microstructures are shown in Figure 3.2. A special mold was designed by Scania CV AB for the bending fatigue specimens to obtain the required surface. The microstructure and graphite morphology have been very similar within the batches, thus it is fair to state that the obtained data and analysis are reliable.
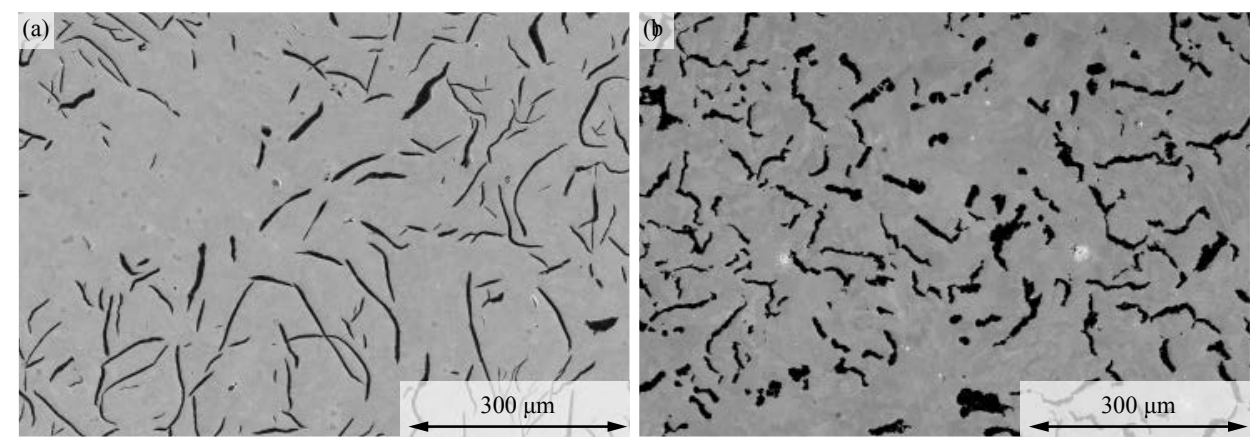

Figure 3.2. The two different cast iron mainly investigated, where (a) is grey cast iron and (b) is compact graphite iron. 


\section{CHAPTER 4}

\section{Shot peening}

Shot peening refers to the cold work process involving small spherical balls that are shot under controlled conditions on the component surface [8]. A schematic of the shot peening process is illustrated in Figure 4.1 .
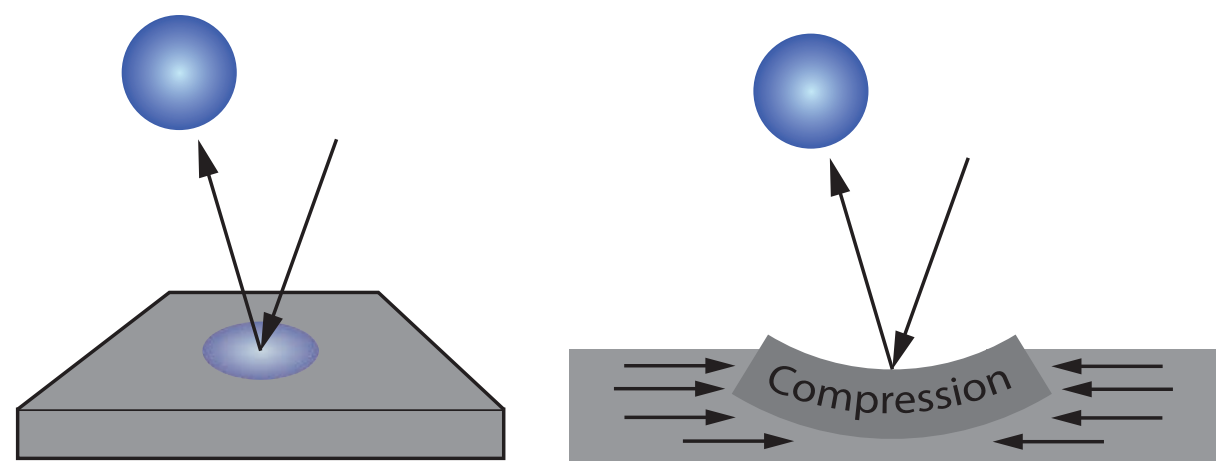

Figure 4.1. An illustration of the shot peening process.

The kinetic energy of the shots will partially be transmitted to the surface at impact and create small indents. Local surface yielding of the material occurs which is constrained by the unaffected bulk, resulting in surface compressive residual stresses. Since shot peening is a controlled surface treatment process, compared to sandblasting, the quality of the peening media has to be specified and controlled, both spheroidal dimensions and the hardness of the media. There are a few important parameters when shot peening such as peening intensity, coverage and impact angle. Peening intensity is given by testing the peening process 
on a standardised steel testing strip, called Almen strip. Parameters affecting the intensity are for example shot size, shot media hardness, nozzle velocity and distance to specimen. Since shot peening results are repeatable, it is considered to be a controlled process.

At the end on World War II, it was commonly accepted and proven that surface residual stresses can be beneficial or detrimental to the fatigue life. As a consequence, much efforts were put to investigate to what extent residual stresses can be introduced to the surface as well as to what depth below the surface. To induce these residual stresses for production line purposes, the process of means was shot peening. Their research was mainly conducted on various spring steels and their pioneering work showed that the kinetic energy transferred played an important role to the fatigue life. Coombs et al. [9] made an attempt to measure the most effective peening affected depth for several different shot peening conditions. To find the depth they removed some material of the specimens and then determined the fatigue life and at a certain depth the maximum cycles to failure were found for all test conditions. Their conclusion was that it exists a compressive residual stress peak at a certain depth below the shot peened surface, resulting in the maximum cycles to failure. Today we consider shot peened steels to have a maximum compressive stress peak just below the peened surface. By screening the literature dealing with shot peening of different steels and its effects on different loadings $[8,10-22]$ it becomes clear that shot peening is an effective and cost efficient post treatment to increase the fatigue strength of steels. Finding the optimum shot peening conditions for steels might be impossible without narrowing down the problem to a specific steel under specific loading conditions [23]. Other materials that have been shot peened and gained an increased fatigue strength are titanium, aluminium and superalloys [24-32], as well as some ceramics [33-35].

\subsection{Shot peening of cast iron}

Lots of research concerning cast iron has been conducted and kept in-house by industry. This has lead to a knowledge gap in the scientific community regarding post processing of cast iron. Instead, most cast iron research has treated the solidification process during the last 15 years. Surprisingly few articles discuss how fatigue properties vary under different loading conditions for different cast irons available today. Even fewer articles are found on the topic of shot peening of cast iron. Most articles deal with spherical cast iron with various microstructures [36-42]. Early work on shot peening of spherical graphite iron showed that the fatigue strength can be increased anywhere from $7-300 \%$ [36, 38, 40, 42, 43]. During my time as a Ph.D. student, I have not found any research on the subject of grey iron and its shot peening effects on fatigue life. 


\section{CHAPTER 5}

\section{Fatigue}

The word fatigue used in engineering has become widely accepted for the damage and failure of materials under cyclic loading. In a report from 1964 by the International Standardization Organization the term fatigue was defined as "applied to changes in properties which can occur in a metallic material due to repeated application of stresses or strains, although usually this term applies specially to those changes which lead to cracking or failure". This description is generally also valid for non-metallic materials. Fatigue is used in various fields of research having different insinuations. In engineering it is often used together with a prefix or a suffix describing the type of fatigue considered. In engineering research the most prominent fatigue genres are mechanical fatigue, creep fatigue, iso-thermal fatigue, thermo-mechanical fatigue, sliding contact fatigue, rolling contact fatigue, corrosion fatigue and fretting fatigue [44-46].

The work done by Wöhler in 1860 on rotary bending of railway axles for the Prussian Railway lead to the classical stress amplitude vs. life curves (S-N curves) which is still used today. He described the concept of a fatigue endurance limit in his pioneering work since one of his test samples were subjected to 132,250,000 cycles without failing. Meaning that the component will not fail if the load is below a certain limit. Nowadays, the terms fatigue strength or fatigue limit refers to what Wöhler called fatigue endurance limit.

\subsection{Fatigue of cast iron}

From the 60's to the mid 80's much work was done on characterizing the mechanical fatigue behaviour of grey and spheroidal graphite iron. During these years, mainly bending and rotary bending fatigue tests were conducted and efforts were made to explain the deformation behaviour in grey and spheroidal graphite iron, which are 
summarised in references [6, 7]. Empirical models, predicting the fatigue life were proposed and different research groups proposed different deformation mechanisms in grey cast iron under tensile and cyclic loading [47-52].

When screening the published articles regarding cast iron and fatigue, it is evident that grey iron lost interest in the 80's whereas the amount of publications concerning ductile cast iron remained fairly unchanged. The amount of publications regarding fatigue behaviour in grey iron has always been a tiny part of the published grey iron articles. The link between different surface conditions and their effects on fatigue strength subjected to various types of loading have not gained much attention from the scientific community until the last couple of decades.

In grey iron, the crack initiation period can be seen as zero $\%$ of the fatigue life which can be compared to the $90 \%$ of the fatigue life proposed for steel $[44,45]$. Due to the poor tensile strength of graphite, deformation starts immediately at the first loading cycle, at least if the fatigue test involves tensile loads. Graphites oriented perpendicular to the loading direction opens at stresses between 0 and $55 \mathrm{MPa}$, depending on matrix strength and local surface residual stresses [47, 53]. The graphite opening results in reduced material stiffness. As a result of the graphite morphology and opening micro cracking and/or crack networking occurs. Fash and Socie [52] concluded that micro cracking and crack networking started during the first cycle at the surface and continued to grow to a size of $1-2 \mathrm{~mm}$.

Cast iron is often considered to have low notch sensitivity due to voids (graphite inclusions)[54]. Therefore, it is convenient to treat graphite in grey iron as preexisting cracks when loaded in tension. In compression the load bearing capacity of graphite is large, which result in a asymmetric tension/compression curve for grey iron as illustrated in Figure 5.1.

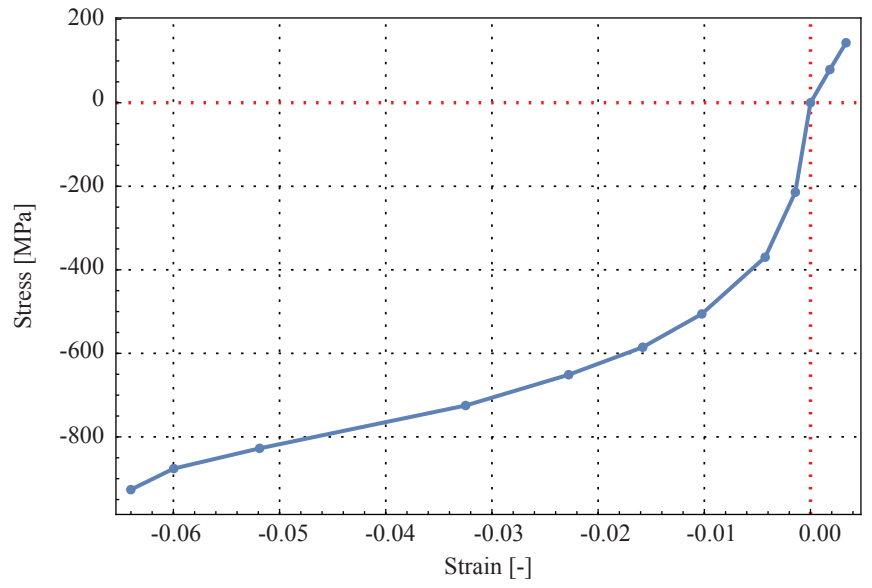

Figure 5.1. General tension/compression behaviour of grey cast iron, redrawn from [55].

Current practice in design criteria of grey cast iron is to use $25-35 \%$ of the ultimate tensile strength as the maximum cyclic tensile stress. Willidal et al. [56] 
showed that $0.07 \%$ strain is a better fatigue strength indicator. They conducted axial fatigue testing using $R=-1$ on different grey iron, all run-out samples had been subjected to a strain level of $0.07 \%$. Both types of cast iron studied in my work have relatively low tensile strength $\sim 300 \mathrm{MPa}$ for the grey cast iron and $\sim 400 \mathrm{MPa}$ for the compact graphite iron. Nevertheless, it is the state of the art material for heavy-duty diesel engine cylinder heads. Reasons for this are the price, thermal conductivity and damping capacity. The cost per each cylinder head manufactured depends not only on the direct casting cost but also on the post treatment needed to obtain the correct dimensions. On the negative side, grey iron has a low fatigue strength in comparison to steels.

\subsection{Residual stresses and fatigue}

It is well-known that surfaces are sensitive to crack initiation under tensile loads due to the lack of constraints. Compressive surface residual stresses can prolong fatigue crack initiation whereas tensile surface residual stresses promotes crack initiation. In a survey on the influence of surface residual stresses on fatigue life by Webster and Ezeilo [57] it is undeniable that residual stresses affect fatigue strength. Luckily, several methods exist to induce compressive surface residual stresses and are summarized in [8]. An example of when tensile residual stresses are likely to be present in critical components are after welding. Two cold work pieces are fused together by molten material and usually cooled down quite rapidly to room temperature. The large temperature difference results in tensile residual stresses in and near the weld. As an example: aluminium alloy weld seams that are typically shot peened yield a $60 \%$ increase in fatigue strength [4] as a result of the compressive residual stresses at the weld. Porokhov and Bogachev [58] showed that different mechanical surface treatments, altering the surface residual stresses, can lead to a increase in fatigue strength of 20-50\% of medium carbon steel. Showing that compressive surface residual stresses can increase fatigue strength.

Depending on the surface finishing as well as machining method used, the resulting residual stress distribution can vary significantly. Also different materials subjected to the same machining parameters can result in different amounts and signs of residual stresses at the surface. Normally the residual stresses are compressive after conventional mechanical machining of ferrous alloys. However, with inadequate parameters the residual stresses can be tensile and have been shown to strongly influence the fatigue strength of steels [10-13, 59]. Gentle grinding of the surface can result in very high compressive surface residual stresses which drop quickly with depth and approaches zero after just $40-80 \mu \mathrm{m}$, resulting in an increased fatigue life of $20-25 \%$ for medium to high strength steels. Ghanem et al. [60] investigated the residual stress distribution after electrical discharge machining (EDM) on a tool steel and the resultant fatigue strength. The test piece was subjected to three-point bending and the fatigue strength was defined at $10^{6}$ cycles. Tensile residual stresses from EDM resulted in a decrease of $35 \%$ compared to milling. Laser treatment have proven to be an effective procedure inducing compressive residual stresses and Belló et al. [59] investigated the effects 
in $50 \mathrm{CrV} 4$ steel. Besides the importance of coverage they found a $40 \%$ increase in fatigue strength due to the residual stress distribution and the microstructural changes of the surface layer.

\subsection{Fatigue testing conducted}

Mechanical fatigue testing under both uniaxial and bending conditions have been conducted within this work. All fatigue testing on cast iron were done by the two industrial partners, Scania CV AB and Volvo Powertrain. Four-point bending of austenitic stainless steel was conducted at the mechanical testing lab at Linköping University by me personally.

No positive effects from shot peening of grey iron subjected to uniaxial loading was seen. It was shown that it is easy to over peen grey iron resulting in reduced fatigue strength. A 30 minute heat treatment at $285{ }^{\circ} \mathrm{C}$ increased the fatigue strength with $\sim 10 \%$.

Bending fatigue of both grey and compact graphite iron showed that shot peening can increase the fatigue strength when using correct peening parameters. The 30 minute heat treatment proved to increase the fatigue strength significantly.

To investigate the residual stress evolution in grey cast iron, push-push and pull-pull testing were also implemented in Paper V.

Testing the surface integrity of austenitic stainless steel were conducted utilizing four-point bending and $2 \times 10^{6}$ cycles as the fatigue limit. 


\section{CHAPTER 6}

\section{Microscopy}

All microscopical investigations of the materials included in this thesis have been done with a Hitatchi SU70 FEG analytical scanning electron microscope. Two SEM techniques were frequently used for material characterisation namely electron channelling contrast imaging (ECCI) and electron backscattering diffraction (EBSD).

\subsection{Electron channelling contrast imaging}

ECCI makes use of the backscattered electron intensity, and dependens on the crystal lattice plane orientation with respect to the incident electron beam. Local distortions in the crystal lattice, due to dislocations or grain boundaries, can cause changes in the backscattered electron intensity. Making it possible to detect defects in the material on a $\mu \mathrm{m}$ scale. The technique has been used to image dislocation structures in metals deformed during fatigue and fracture, to quantitatively characterise dislocation structures (Burgers vector analysis), and to image varying structures with higher contrast. The main technical drawback being the requirement of a large final aperture to allow the beam to cover a large angular regime, resulting in a spatial resolution of $\sim 2 \mu \mathrm{m}$, which is almost two orders of magnitude above the resolution of $\operatorname{EBSD}[61,62]$. This reduces the technique for dislocation imaging to lightly deformed materials.

\subsection{Electron backscatter diffraction}

EBSD is an additional characterisation technique used to determine grain orientations, local texture, point-to-point correlations as well as phase identification of both the surface and bulk material. 
The first observation of a diffraction pattern in backscattering mode was reported in 1928 by Nishikawa and Kikuchi. They discussed that while doing transmission electron microscopy there should exist a diffraction pattern for both the transmitted electrons as well as the backscattered electrons. They successfully placed a recording film in front of the specimen and captured the backscattered diffraction pattern. The same technique for obtaining the diffraction pattern, often referred to as Kikuchi patterns or EBSD patterns, are still in use today in SEM with some changes in term of specimen orientation in relation to the beam and detector specifications [63].

EBSD patterns are generated on a flat phosphor screen by backscatter diffraction of the beam from the surface down to a depth of $\sim 20 \mathrm{~nm}$, while the specimen is at a $20^{\circ}$ tilt away from the beam. The characteristic feature of the backscattered Kikuchi pattern is the arrangement of parallel bright bands instead of the regular diffraction spots generated in the TEM of the diffraction area. The geometry of the EBSD pattern can be thought of as a gnomonic projection of the crystal lattice on the phosphor screen. The lattice planes can be imagined to be stretched out so that they intersect with the phosphor screen in the middle of their related Kikuchi pattern as shown in Figure 6.1 where the basic geometries of EBSD are illustrated.
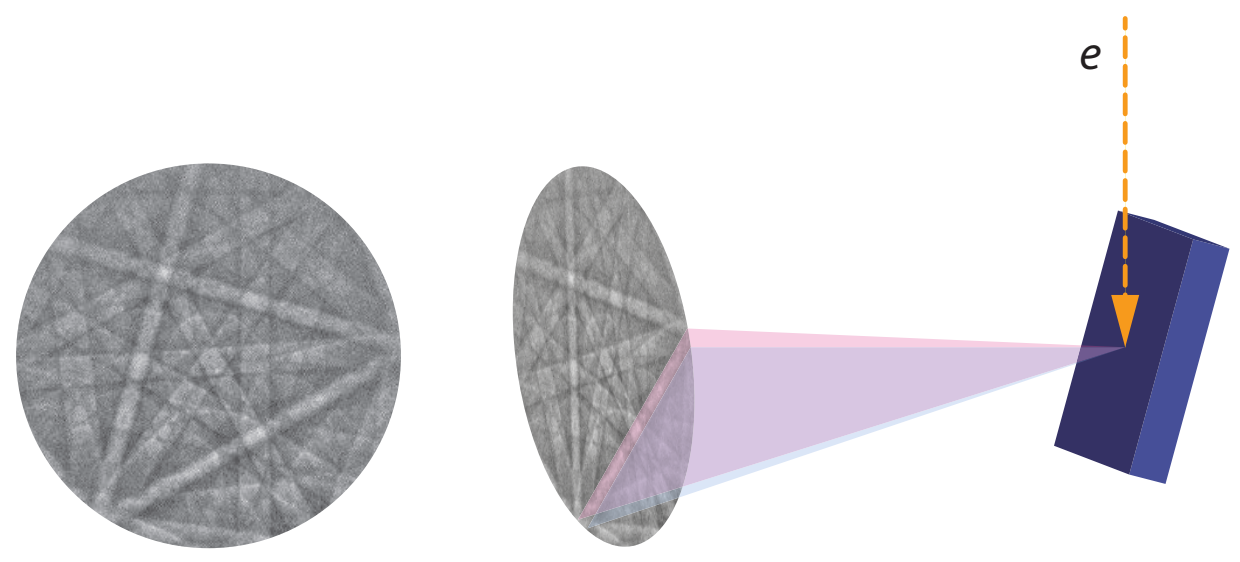

Figure 6.1. Principal of Kikuchi pattern detection.

When several Kikuchi bands are considered for the crystal orientation analysis, the angles between the projected plane correspond to the angles between the diffraction planes. Moreover, the angular width of a specific Kikuchi band is connected to the interplanar spacing, $d_{h k l}$, according to Bragg's law Eq 2.1. Here, $\lambda$ is the electrons wavelength from the incident beam which depend on the acceleration voltage. Complete information of grain orientation can then be calculated. Since the quality of the beam strongly affects the Kikuchi patterns, the type of filament, acceleration voltage, beam alignment and beam control contributes to the accuracy of the technique. 


\subsection{Differences between ECCI and EBSD}

To simplify the two main differences between the two techniques are the detectors and sample orientations, as depicted in Figure 6.2. With ECCI, every pixel has information from the scanned sample surface. Whereas for EBSD every point from the scanning is displayed over the whole detector and every mapped position yields information of the crystal orientation.

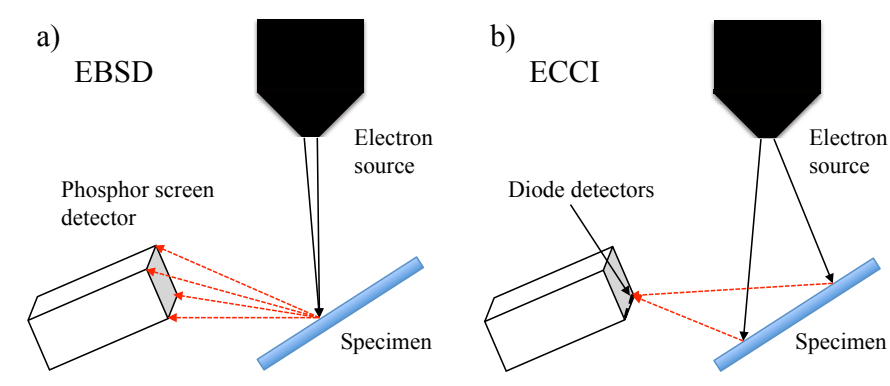

Figure 6.2. Illustrating the difference between (a) EBSD and (b) ECCI. Courtesy of Jonas Saarimäki. 


\section{CHAPTER 7}

\section{Review of appended publications}

\section{Paper I - Residual stresses in shot peened grey and compact iron}

Contribution: I performed most of the residual stress measurements and instrumentation and have been the main contributor regarding the evaluation and responsible for manuscript writing.

RQ addressed: RQ1, RQ2

With the material investigation conducted leading to this publication it was evident that it is possible to measure residual stresses in cast iron both fast and with high repeatability. Some concern still existed, as often is with XRD, regarding how accurate the measured stresses are. Nevertheless, RQ1 was addressed and well answered.

While shot peening effects on steels, aluminium, titanium and superalloys have been extensively studied, published articles on cast iron are scarce. Very few articles on shot peening of grey or compact iron was found in the literature survey. So the investigation question was RQ2: "Can shot peening be used to induce beneficial residual stresses in cast iron" This was not obvious due to many sayings and accepted "facts". Small pucks of grey and compact iron were manufactured by Volvo and Scania respectively and shot peened by Ytstruktur in Arboga, Sweden. Residual stress profiles with depth were produced to compare the effects of peening intensity, coverage and shot size. The results were the platform upon which the project continued. What was highly wanted were residual stress profiles showing the same characteristic shape as seen for shot peened steels for improved fatigue strength. Based on this the RQ2 were partially answered, fatigue testing were needed to verify our findings. 


\section{Paper II - Shot peening induced plastic deformation in cast iron}

Contribution: I performed most of the residual stress measurements and instrumentation and have been the main contributor regarding the microstructure investigation, evaluation and responsible for manuscript writing.

RQ addressed: RQ1, RQ2, RQ4

In this paper, a method for quantifying the amount of plastic deformation of the shot peened surface of the cast iron tested in Paper I, by other means than XRD. With EBSD the low angle grain boundary (LAGB) density can be calculated. If the misorientation angle was between $1.5^{\circ}$ and $10^{\circ}$ it was treated as plastically induced deformation from the shot peening. Non-indexed data points were treated as plastically deformation. However, graphite was also non-indexed leading to a base-line for LAGB density in cast iron. This results in the need for large enough EBSD maps to obtain a good average distribution of the LAGB density due to graphite morphology. Considerable amounts of plastic deformation could be induced to a great depth. Residual stress profiles and LAGB profiles converges to a "steady state" level at roughly the same depth below the shot peened surface. The same conclusions could be made if the surface had been machined. As a result, the method of using EBSD and LAGB density plots can be used as a tool to estimate the depth and amount of residual stresses in cast iron. A great correlation between the XRD and the LAGB density plots proves that EBSD can utilized as a complementary method for residual stress evaluations. Elastic and plastic deformation from the shot peening were observed however the dominating deformation mechanisms could not be fully answered.

\section{Paper III - In-situ SEM/EBSD study of deformation and fracture} behaviour of flake cast iron

Contribution: I contributed with the microstructural investigation, instrumentation and evaluation together with Ph.D. Mattias Calmunger. I was the main responsible for manuscript writing.

RQ addressed: RQ4

With this work, the elusive nature of grey iron was revealed. EBSD maps done when the sample was subjected to tensile loading were believed to provide information regarding plastic deformation in grey iron. The analysis of the experiment showed that plastic deformation, such as grain rotation, internal grain rotation and local yielding at graphite tips, were so small that the EBSD data could not be used as proof of their existence, until the very end of the loading. However, in the SEM it was easy to observe that the material was deformed during tensile loading. The flake graphites cracked and opened at loads below $40 \mathrm{MPa}$. With increasing loads, more and more graphites opened up, both one, two and three times inside the graphite as well as delamination of the graphite matrix interface. Deformation development under static loading of grey cast iron were quite well seen and addressed. 


\section{Paper IV - Fatigue strength of machined and shot peened grey cast iron}

Contribution: I performed most of the residual stress measurements and instrumentation and have been the main contributor regarding the microstructure investigation, evaluation and responsible for manuscript writing. Maqsood Ahmad did the fatigue testing.

RQ addressed: RQ1, RQ3, RQ4

The fatigue strength of grey iron in push-pull conditions $(R=-1)$ of machined and shot peened samples was derived. Samples with and without a neck radius $\left(k_{t}=1.33\right)$ were tested. Residual stress measurements and SEM investigations were conducted on samples prior to testing and on fatigued samples. Grey iron are not particular sensitive to notches, which was evident for the two sample geometries tested. While both shot peening conditions tested showed now significant improvement in fatigue strength, a $30 \mathrm{~min}$ annealing heat treatment at $285^{\circ} \mathrm{C}$ of the gently shot peened samples increased the fatigue strength. A decrease in fatigue strength of $\sim 15 \%$ was the result of the heavy shot peening parameters tested. These parameters showed a similar residual stress profile as for shot peened steels. The fatigue strength of the machined samples were used as a baseline. Microstructural investigations could not provide clear information on why the $30 \mathrm{~min}$ annealing treatment had such a positive effect on the fatigue strength, nor why the heavy shot peening had such a negative effect. No significant differences were observed between the machined and the gentle shot peened samples either. The one thing which was clearly observed was the vast amount of cracks in the run-out fatigue samples. RQ1 had already been well answered and now put to the test with another geometry of the sample. Still working fine. RQ3 were addressed but clearly not answered with only the conducted shot peening. With the help from a 30 minute heat treatment it was possible to get a small increase in fatigue strength. Investigations of RQ4 did not provide any more clear finding regarding the deformation mechanisms other than the previously seen crack networking.

Paper V - Residual stresses in uniaxial cyclic loaded pearlitic lamellar graphite iron

Contribution: I performed the residual stress measurements and instrumentation and have been the main contributor regarding the evaluation and responsible for manuscript writing.

RQ addressed: RQ4

Test samples were normalised in order to investigate the residual stress development under cyclic loading in grey iron. Normalised by means of conventional stress relieving heat treatment followed by carefully grinding and polishing. One sample was tested in tension, one in compression and one in tension/compression and a fourth sample was used as a reference. The idea for this paper was to test if it was possible to induce residual stresses, either positive or negative, in the sur- 
face region during uniaxial loading. A higher load than that used for testing the fatigue strength were used to induce a larger plastic zone, which would be easier to detect using XRD. The test revealed that no changes of residual stresses could be detected. Thus, residual stresses are not of great importance to the fatigue strength of grey iron subjected to uniaxial loading.

\section{Paper VI - Effective X-ray elastic constant of cast iron}

Contribution: I performed the residual stress measurements and instrumentation as well as the mechanical testing and have been the main contributor regarding evaluation and responsible for manuscript writing.

RQ addressed: RQ1

While XRD measures strains with the $\sin ^{2} \psi$-method, the conversion of strains into stresses utilizes XEC. To get reliable stress data, the need for an accurate XEC is evident and has been exemplified in Chapter 2. Normally, the theoretical XEC for the ferritic phase and plane of measurement are used. This can result in a misleading interpretation of the stresses in the material. With cast iron, having such a high concentration of carbon and several other alloying elements, the XEC needs proper investigating to give a better understanding of the induced residual stresses. Samples of fully pearlitic grey iron, $90 \%$ pearlitic compact graphite iron, fully ferritic spheriodal graphite iron and fully pearlitic steel were examined. The cast iron were tested in uniaxial loading as well as in four-point bending, both in tension and in compression to ensure if different testing methods could provide the same effective XEC value. No significant differences in effective XEC could be determined between the different testing methods used for calibrating the XEC. The different cast iron have more or less the same effective XEC, in their normalised condition. Clearly the need for investigation of the effective XEC still exists for strained material since the spheroidal graphite iron with a strained surface showed a big difference in effective XEC. The effective XEC derived for the pearlitic steel were well in-line with that found in literature.

Paper VII - Surface integrity and fatigue behaviour of electric discharged machined and milled austenitic stainless steel

Contribution:I performed the residual stress measurements, instrumentation and fatigue testing and have been the main contributor regarding the microstructure investigation, evaluation and responsible for manuscript writing.

RQ addressed: RQ5

Residual stress measurement, SEM investigations and fatigue testing were conducted on an austenitic stainless steel (AISI 304). This work builds on the curiosity of how much deformation will be induced in the surface after machining, and how it affects the surface integrity and fatigue properties. Milling and EDM effects on surface integrity of normalised AISI 304 were tested. Residual stress profiles 
were determined for both conditions as well as deformation characteristics using SEM, both qualitatively an quantitatively with LAGB density plots. For testing the surface integrity, high cycle fatigue four-point bending tests were conducted with a fatigue cycle limit of $2 \times 10^{6}$ cycles. The fatigue strength for the different surface conditions were investigated. It was revealed that the machined surface had a well-defined fatigue strength, whereas the EDM surface did not provide any clues regarding fatigue strength. Conventional milling induces a strained surface layer and the loading response could be divided into the following three parts. Part one: plastic deformation. Part two: "steady state", no apparent increase in plastic deformation. Part three: final fracture. The EDM sample did not show evidence of clear stages. The first few hundred cycles induced more accumulated plastic deformation than the rest of the test. An interesting point for the EDM samples were that none of them fractured. Surface conditions are thus important to know for austenitic stainless steels when analysing its fatigue properties. RQ5 were very well answered.

\section{Paper VIII - 3D residual stresses in selective laser melted Hastelloy $X$}

Contribution: I performed every vital step together with my joint first coauthor Jonas Saarimäki. Performing residual stress measurements, instrumentation, microstructural investigation, evaluation and manuscript writing.

RQ addressed: RQ5

Additive manufacturing is one of the most hyped topics today in materials research. Characterisation of the microstructure and the mechanical properties needs to be investigated on this new material group. There are many parameters that need considering in order to achieve the desired mechanical properties. In this work, the residual stresses in an as-built cylindrical sample were investigated from the build plate with means of triaxial stress state. Considerable in plane tensile residual stresses were found and minute shearing components. Thus, it can be of great importance to measure the residual stresses in additively manufactured components so that detrimental residual stresses are avoided.

This study encountered a few typical problems with XRD analysis. Firstly, the choice of diffraction plane(s) when using a Cr X-ray tube. Secondly, what XEC:s should be used. Thirdly, what $d_{0}$ would be the most correct. And finally, how do we determine $d_{0}$ accurately enough to get reliable residual stress data. Since the X-ray machine was equipped with a Cr-tube, the 220 diffraction plane provides the highest diffraction angle of $2 \theta \approx 128^{\circ}$. The XEC:s used for this analysis was calculated using the macroscopic values for both the Young's modulus and Poisson's ratio found in literature instead of calculating them from single crystal values. For triaxial stress calculations, it is important to use the correct $d_{0}$. Determine the unstressed lattice parameter was be done using the same raw powder used in the additive manufacturing process. The choice of $d_{0}$ might not be accurate enough for the triaxial stress state calculations since a small change in unstressed lattice spacing affects the stress calculations considerably. Since it is 
possible that there is a small change in lattice spacing from the raw powder to the final product. RQ5 were addressed and well answered on the parts investigated.

\subsection{Scientific contribution}

The Swedish higher education act states "The mandate of higher education institutions shall include third stream activities and the provision of information about their activities, as well as ensuring that benefit is derived from their research findings". Thus, it is my responsibility as a researcher to motivate how my research contributes not only the research community but also society in general.

Residual stresses and deformation behaviour of cast iron in heavy-duty diesel engines have been investigated in this Ph.D. thesis. Understanding of the fatigue response of cast iron is important to improve their efficiency by increasing the working pressure and temperature. Yielding a more effective combustion cycle, ultimately reducing harmful emissions. The findings have been communicated to the research community via conferences and journal articles. 


\section{CHAPTER 8}

\section{Outlook}

With complex microstructure comes a complex deformation behaviour, this is especially true for grey and compact graphite iron. In my opinion this thesis work has only scratched the surface concerning the fatigue behaviour of grey and compact graphite iron. Some parts have been partially clarified such as shot peening effects on fatigue strength, residual stresses and deformation. But there is still vast amounts left to be discovered.

For future work, several aspects of taming the understanding of deformation behaviour in cast iron are open for researchers world wide to dig in to. I would recommend the following as a start:

1. Studies on the deformation induced during static and cyclic loading in both grey and compact graphite iron in-situ SEM. Preferably with different surface conditions of the test sample such as machined, EDM, shot peened and with casting skin.

2. Cast iron components will keep the casting skin more or less intact upon service. Sand blasting is used today to clean the cast component from the mold. Sand blasting is a rough method often performed while the cast is still warm. Should it be done when the cast has reached room temperature or when the cast is still hot. Also, it would be interesting to investigate the effects of shot peening on fatigue performance with the casting skin still present.

3. Why does the 30 min heat treatment enhance the fatigue strength in cast iron. A research team in America proposed a FeN precipitate ranging from 2-4 $\mathrm{nm}$ to be the beneficial precipitate for the increased fatigue strength. Their existence have been supported by synchrotron experiments but not by other techniques. However, in my research I have encountered much larger 
precipitates $(1-2 \mu \mathrm{m})$ after the heat treatment and their origin, nature and effects for fatigue strength is unknown. 


\section{CHAPTER 9}

\section{List of publications}

[I] In-situ SEM/EBSD study of deformation and fracture behaviour of flake cast iron

M. Lundberg, M. Calmunger, R. L. Peng

13th International Conference on Fracture, Beijing, China (2013).

[II] Fatigue strength of shot peened compacted graphite iron

R. L. Peng, T. Vuoristo, D. Bäckström, M. Ahmad,

M. Lundberg, S. Johansson

12th International Conference on Shot Peening, ICSP-12, Goslar, Germany (2014).

[III] Influence of shot peening parameters on residual stresses in flake and vermicular cast irons

M. Lundberg, R. L. Peng, M. Ahmad, D. Bäckström,

T. Vuoristo, S. Johansson

Materials Science Forum, 768-769, 534-541 (2014).

[IV] Graphite morphology's influence on shot peening results in cast irons

M. Lundberg, R. L. Peng, M. Ahmad, D. Bäckström,

T. Vuoristo, S. Johansson

Materials Science Forum, 768-769, 542-549 (2014). 
[V] Residual stresses in shot peened grey and compact iron M. Lundberg, R. L. Peng, M. Ahmad, D. Bäckström,

T. Vuoristo, S. Johansson

HTM-Journal of Heat Treatment and Materials, 69, (1), 38-45 (2014).

[VI] Shot peening induced plastic deformation in cast iron - Influence of graphite morphology

M. Lundberg, R. L. Peng, M. Ahmad, D. Bäckström,

T. Vuoristo, S. Johansson

HTM-Journal of Heat Treatment and Materials, 69, (2), 106-113 (2014).

[VII] Analysis of residual stress in stress harps of grey iron by experiment and simulation

P. Schmidt, R. L. Peng, V. Davydov, M. Lundberg, M. Ahmad,

T. Vuoristo, D. Bäckström, S. Johansson

Advanced Materials Research, 996, 586-591 (2014).

[VIII] Characterization of Hastelloy X produced by laser powder bed additive manufacturing

J. Saarimäki, M. Lundberg, J. J. Moverare, H. Brodin

World PM2016, Hamburg, Deutschland (2016).

[IX] Residual stresses in uniaxial cyclic loaded pearlitic lamellar graphite iron

M. Lundberg, J. Saarimäki, R. L. Peng, J. J. Moverare

Materials Research Proceedings, 2, 67-72 (2016).

[X] 3D residual stresses in AM SLM Hastelloy $\mathrm{X}^{\mathrm{TM}}$

J. Saarimäki, M. Lundberg, J. J. Moverare, H. Brodin

Materials Research Proceedings, 2, 73-78 (2016).

[XI] Surface integrity and fatigue behaviour of electric discharged machined and milled austenitic stainless steel

M. Lundberg, J. Saarimäki, J. J. Moverare, M. Calmunger

Materials Characterization, 124, 215-222 (2017). 
[XII] Effective X-ray elastic constant of cast iron M. Lundberg, J. Saarimäki, J. J. Moverare, R. L. Peng Journal of Materials Science, 53,(4), 2766-2773 (2018).

[XIII] Grain size depending dwell-fatigue crack growth in Inconel 718 J. Saarimäki, M. Lundberg, J. J. Moverare Advanced Engineering Materials, 1-7 (2018).

[XIV] Dwell-fatigue crack propagation in additive manufactured Hastelloy $\mathrm{X}$

J. Saarimäki, M. Lundberg, H. Brodin, J. J. Moverare Materials Science and Engineering A, 722, 30-36 (2018). 


\section{Bibliography}

[1] I. C. Noyan and J. B. Cohen. Residual stress. Springer-Verlag New York Inc., 1987.

[2] V. Hauk. Structural and residual stress analysis by nondestructive methods. Elsevier B.V., 1997.

[3] P. J. Withers and H. K. D. H. Bhadeshia. "Residual stress. Part 2 Nature and origins". In: Materials Science and Technology 17.4 (2001), pp. 366-375.

[4] M. E. Hilley, ed. Residual stress measurement by X-ray diffraction - SAE J784a. 1971.

[5] V. Hauk and U. Wolfsteig. "Röntgenographische Elastizitätskonstanten". In: Journal of Heat Treatment and Materials 31.1 (1976), pp. 38-42.

[6] J. R. Davis, ed. ASM specialty handbook cast irons. ASM International, 1996.

[7] F. Charles. Gray and ductile iron castings handbook. Ed. by C. F. Walton. Gray and ductile iron founders' society inc., 1971.

[8] V. Schulze. Modern Mechanical Surface Treatment. Wiley-VCH Verlag GmbH, 2005 .

[9] A. G. H. Coombs, F. Sherratt, and J. A. Pope. "An analysis of the effects of shot peening upon the fatigue strength of hardened and tempered spring steel". In: Fatigue of Metals. 1956.

[10] F. P. Smaglenko, B. A. Gryaznov, and S. S. Gorodetskii. "Influence of machining methods on the residual stress distribution and fatigue strength of steel ShKh15 specimens". In: Strength of Materials 9.2 (1977), pp. 145-150.

[11] B. T. Troshchenko, A. V. Prokopenko, and S. M. Lyalikov. "Effect of residual stresses on the fatigue resistance of structural steels and alloys containing surface defects". In: Strength of Materials 21.8 (1989), pp. 975-981. 
[12] K. Dalaei and B. Karlsson. "Influence of shot peening on fatigue durability of normalized steel subjected to variable amplitude loading". In: International Journal of Fatigue 38 (2012), pp. 75-83.

[13] K. Dalaei, B. Karlsson, and L. E. Svensson. "Stability of residual stresses created by shot peening of pearlitic steel and their influence on fatigue behaviour". In: Procedia Engineering 2.1 (2010), pp. 613-622.

[14] M. Torres and H. Voorwald. "An evaluation of shot peening, residual stress and stress relaxation on the fatigue life of AISI 4340 steel". In: International Journal of Fatigue 24.8 (2002), pp. 877-886.

[15] K. Dalaei and B. Karlsson. "Influence of overloading on fatigue durability and stability of residual stresses in shot peened normalized steel". In: Materials Science and Engineering A 528.24 (2011), pp. 7323-7330.

[16] N. M. Rudnitskii. "Evaluation of the effect of residual stresses and surface layer hardening on the fatigue strength of components". In: Strength of Materials 13 (1981), pp. 1220-1226.

[17] M. Widmark. "Effect of material, heat treatment, grinding and shot peening on contact fatigue life of carburised steels". In: International Journal of Fatigue 21 (1999), pp. 309-327.

[18] A. V. Korznikov et al. "Influence of severe plastic deformation on structure and phase composition of carbon steel". In: Nanostructured Materials 4.2 (1994), pp. 159-167.

[19] Y. Harada, K. Fukauara, and S. Kohamada. "Effects of microshot peening on surface characteristics of high-speed tool steel". In: Journal of Materials Processing Technology 201.1-3 (2008), pp. 319-324.

[20] S. Wang et al. "Compressive residual stress introduced by shot peening". In: Journal of Materials Processing Technology 73.1-3 (1998), pp. 64-73.

[21] J. W. Zhang et al. "Analysis on fatigue property of microshot peened railway axle steel". In: Materials Science and Engineering A 528.3 (2011), pp. 16151622 .

[22] A. M. Eleiche, M. M. Megahed, and N. M. Abd-Allah. "The shot-peening effect on the HCF behavior of high-strength martensitic steels". In: Journal of Materials Processing Technology 113.1-3 (2001), pp. 502-508.

[23] B. Bhuvaraghan, S. M. Srinivasan, and B. Maffeo. "Optimization of the fatigue strength of materials due to shot peening: A survey". In: International Journal of Structural Changes in Solids 2.2 (2010), pp. 33-63.

[24] J. T. Cammett and P. S. Prevéy. "The effect of shot peening coverage on residual stress, cold work and fatigue in a nickel-base superalloy". In: 9th International Conference on Shot Peening. 2005, pp. 429-435.

[25] Y. Chen and R. Wang. "Investigation on the effect of shot peening on elevated temperature fatigue behavior of superalloy". In: 3rd International Conference on Shot Peening. 1987, pp. 655-666. 
[26] E. Hornbogen and C. Verpoort. "Influence of surface treatments on fatigue crack initiation in $\gamma+\gamma^{\prime}$ precipitation hardening alloys". In: Superalloys ' 80 . 1980, pp. 585-593.

[27] T. Dörr et al. "Influence of shot peening on fatigue performance of highstrength aluminium - and magnesium alloys". In: 7th International Conference on Shot Peening. 1999, pp. 153-160.

[28] L. Wagner and G. Lutjering. "Influence of shot peening on the fatigue behavior of titanium alloys". In: 1st International Conference on Shot Peening. 1981, pp. 453-460.

[29] J. Lindemann, C. Buque, and F. Appel. "Effect of shot peening on fatigue performance of a lamellar titanium aluminide alloy". In: Acta Materialia 54.4 (2006), pp. 1155-1164.

[30] L. Wagner. "Mechanical surface treatments on titanium, aluminum and magnesium alloys". In: Materials Science and Engineering: A 263.2 (1999), pp. 210-216.

[31] E. C. Reed and J. A. Viens. "The influence of surface residual stress on fatigue limit of titanium". In: Journal of Engineering for Industry 82 (1960), pp. $76-78$.

[32] R. John et al. "Stability of shot peen residual stresses in IN100 subjected to creep and fatigue loading". In: Procedia Engineering 2.1 (2010), pp. 18871893.

[33] W. Pfeiffer and J. Wenzel. "Shot peening of brittle materials - status and outlook". In: Material Science Forum 638-642 (2010), pp. 799-804.

[34] K. Kubiak, S. Fouvry, and A. M. Marechal. "A practical methodology to select fretting palliatives: Application to shot peening, hard chromium and WC-Co coatings". In: Wear 259.1-6 (2005), pp. 367-376.

[35] K. Takahashi et al. "Improvement of strength and reliability of ceramics by shot peening and crack healing". In: Journal of the European Ceramic Society 30.15 (2010), pp. 3047-3052.

[36] Y. Ochi et al. "Effect of shot-peening treatment on high cycle fatigue property of ductile cast iron". In: International Journal of Fatigue 23.5 (2001), pp. 441-448.

[37] S. Parent-Simonin, J. Fargues, and J. F. Flavenot. "Shot peening of nodular cast iron". In: 2nd International Conference on Residual Stress. 1989, pp. $883-888$.

[38] E. Satoru et al. "Effects of shot peening and heat treatment on endurance limits of austempered ductile cast iron gears". In: 6th International Conference on Shot Peening. 1996, pp. 14-23.

[39] S. Ji, K. Roberts, and Z. Fan. "Effect of shot peening on fatigue performance of ductile iron castings". In: Materials Science and Technology 18.2 (2002), pp. 193-197. 
[40] A. Ebenau et al. "Influence of shot peening on the microstructure and the bending fatigue strength of bainitic-austenitic nodular cast iron". In: 4th International Conference on Shot Peening. 1990, pp. 389-398.

[41] D. Kirk and D. G. Birch. "Residual stresses induced by peening austenitic ductile cast iron". In: 7th International Conference on Shot Peening. 1999, pp. $23-32$.

[42] A. Zammit et al. "Influence of shot peening on the fatigue life of $\mathrm{Cu}-\mathrm{Ni}$ austempered ductile iron". In: Materials Science and Engineering A 545 (2012), pp. 78-85.

[43] A. T. DeLitiza. "Shot peening for improved castings". In: Modern Casting (1982), pp. 26-28.

[44] S. Suresh. Fatigue of materials. 2nd ed. Cambridge: Cambridge university press, 2006.

[45] R. W. Hertzberg, R. P. Vinci, and J. L. Hertzberg. Deformation and fracture mechanics of engineering materials. 5th ed. 2013.

[46] J. A. Ewing and J. C. Humfrey. "The fracture of metals under rapid alternations of stress". In: Philosophical Transactions of the Royal Society A200 (1903), pp. 2415-250.

[47] A. Fontaine and G. Zambelli. "Damage parameters of lamellar grey cast iron in tension". In: Journal of Materials Science 20.11 (1985), pp. 4139-4146.

[48] L. Haenny and G. Zambelli. "The stiffness and modulus of elasticity of grey cast iron". In: Journal of Materials Science Letters 2 (1983), pp. 239-242.

[49] L. Haenny and G. Zambelli. "Strain mechanisms in grey cast iron". In: Engineering Fracture Mechanics 18.2 (1983), pp. 377-387.

[50] L. Haenny and G. Zambelli. "The role of the matrix graphite interaction in the tensile behaviour of grey cast iron". In: Engineering Fracture Mechanics 19.1 (1984), pp. 113-121.

[51] D. J. Weinacht and D. F. Socie. "Fatigue damage accumulation in grey cast iron". In: International Journal of Fatigue 9.2 (1987), pp. 79-86.

[52] J Fash and D F Socie. "Fatigue behaviour and mean effects in grey cast iron". In: International Journal of Fatigue 4.3 (1982), pp. 137-142.

[53] J. R. Dryden and G. R. Purdy. "The effect of graphite on the mechanical properties of cast irons". In: Acta Metallurgica 37.7 (1989), pp. 1999-2006.

[54] N. Costa, N. Machado, and F. S. Silva. "Influence of graphite nodules on fatigue limit of nodular cast iron". In: Ciência e Tecnologia dos Materiais 20 (2008), pp. 120-127.

[55] D. Kirk. Ductility and strength properties of shot peened surfaces. Tech. rep. 2006, pp. 24-28.

[56] Th Willidal, W. Bauer, and P. Schumacher. "Stress/strain behaviour and fatigue limit of grey cast iron". In: Materials Science and Engineering A 413-414 (2005), pp. 578-582. 
[57] G. A. Webster and A. N. Ezeilo. "Residual stress distributions and their influence on fatigue lifetimes". In: International Journal of Fatigue 23 (2001), pp. 375-383.

[58] V. S. Porokhov and M. N. Bogachev. "Influence of residual stresses on the fatigue resistance of $30 \mathrm{KhGSA}$ steel". In: Metallovedenie i Termicheskaya Obrabotka Metallov 8 (1966), pp. 68-69.

[59] J. M. Belló et al. "Fatigue performance and residual stresses in laser treated 50CrV4 steel". In: Journal of Materials Science 29.19 (1994), pp. 5213-5218.

[60] F. Ghanem et al. "Effect of near-surface residual stress and microstructure modification from machining on the fatigue endurance of a tool steel". In: Journal of Materials Engineering and Performance 11.6 (2002), pp. 631-639.

[61] I. Gutierrez-Urrutia, S. Zaefferer, and D. Raabe. "Electron channeling contrast imaging of twins and dislocations in twinning-induced plasticity steels under controlled diffraction conditions in a scanning electron microscope". In: Scripta Materialia 61.7 (2009), pp. 737-740.

[62] R. J. Kamaladasa and Y. N. Picard. "Basic principles and application of electron channeling in a scanning electron microscope for dislocation analysis". In: Microscopy: Scince, Technology, Aplications and Education 3 (2010), pp. 1583-1590.

[63] A. J. Schwartz, M. Kumar, and B. L. Adams. Electron backscatter diffraction in materials science. Ed. by D. P. Field. Springer Science, 2009. 


\section{Papers}

The papers associated with this thesis have been removed for copyright reasons. For more details about these see:

http://urn.kb.se/resolve?urn=urn:nbn:se:liu:diva-150783 
Final words:

That's the way the rays diffract! 